$P-609$ guinea pig prostatic smooth muscle の in vitro 培类系での収縮能

$$
\begin{aligned}
& \text { 札幌医科大学䎵尿器科 }{ }^{11} \text { ，札幌医科大学第二病理 }{ }^{21} \text {, 古屋病院 }{ }^{31} \\
& \text { 三熊直人 }{ }^{11} \text { ，塚本泰司 }{ }^{11} \text { ，磯村 洋 }{ }^{21} \text { ，古屋聖児 }{ }^{32}
\end{aligned}
$$

【目的】前立腺肥大症 (BPH) における排尿障害の程度は前立腺内の smooth muscle volume と関係しており, a 1-blockerの投与が BPH の非観血的治療の一つとなっている。しかし，排尿障害に関与する前立腺平滑筋の

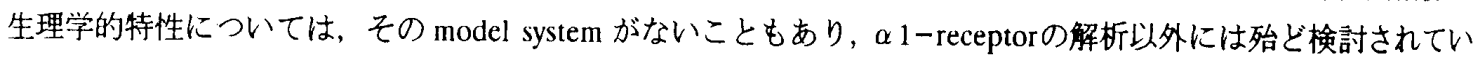
ない。そこで我々は前立腺平滑筋の in vitro 培養系を確立し, その平滑筋としての特性について組織学的に免 疫組織化学および電䫓を用い，また薬理学的に $\alpha 1-$ stimulantによる収縮性から検討した。【対象と方法】エーテル 麻酔下に immature guinea pig (body weight 250-300g) の前立腺を摘出し, 細切後 collagenase, hyaluronidase による䣼素処理および gentle pipetting で single cell suspension とした後, DMEM（含 $10 \% \mathrm{FBS}, 100 \mathrm{U} / \mathrm{m} \ell$ penicillin, $100 \mathrm{mg} / \mathrm{m} \ell$ streptomycin, $2.5 \mathrm{mg} / \mathrm{m} \ell$ amphotericin B ) で resuspend $し$, collagen type I で coating され た petri dish 上で培養を開始した。培養平滑笳細胞は 2-4回の passage 後に実験に用いた。免疫組織化学的検 討のためにはLab-Tech chamber 上で培美した平滑筋細胞を抗 desmin 抗体を用いて免疫染色した。電顕によ る検討のためには，collagen-coated petri dish で培養した平滑筋細胞を用いた。収縮能については 35 mm petri dish 上で confluent culture となった細胞を用い， selective $\alpha$ 1-stimulantである phenylephrine に対する反応性 から検討した。【結果】培美細胞は抗 desmin 抗体によって染色され，また電頭上 myofilament の存在が確認 されたことより平滑筋細胞であることが証明された。さらに，培荃平滑笳細胞は $10^{-6} \mathrm{M}$ phenylephrine に対 して明確な収縮反応を示した。【結語】我々は前立腺平滑竻を研究するための model system として guinea pig 前立腺の in vitro 培養系を確立し, その平滑筋としての組織学的, 薬理学的特性について検討した。今後, さ らにホルモン環境の変化が培養平滑筋細胞の収縮性に与える影㗽などについて検討する予定である。

\title{
$P-610$ 前立腺を支配する交感神経の交叉性
}

\section{東京医科科大学泌尿器科11，同保健街生学科2) \\ 䤡田成芳1)，木原和徳1)，佐藤健次2)，福田博志1)，米攧淳二1)，大島博幸1)}

【目的】交感神経の前立腺に対する支配様式については解剖学的に十分な検討がなされていない. 今回われわれは腰内荿神释の前立腺両葉に対する支配粎式を解剖学的に神経を同定して検討した. 【対象と方法】雑種雄成犬を対象とし，ベントバルビタール麻西下に腰内蔵神経，下腹神経，後 (下) 腸間膜動脈神経渡を露出した，各腰内蔵神経を切断し，その末梢側にに電気刺激を加え，前 立腺両葉にフォーストランスデューサを縫合固定して被膜仪縮を測定するとともに前立腺に割を 入れ前立腺液の分泌を観察した. 刺激条件は $8 \mathrm{~V}, 2 \mathrm{msec}, 10 \mathrm{~Hz}, 20$ 秒間とした. その後片側の下腹 神経を切断し，同様の湘定を繰り返した，実験後全頭を解剖し刺激神経を確認した。

【結果】1) 左右いずれの腰内臓神経の刺激でも前立腺両葉の収縮および前立腺液分泌を認めた。

2)右下腹神経を切断した 8 頭すべてで右腰内臓神経の刺激による前立腺両葉の收縮, 前立腺液の分 泌を認めた。3)左下腹神経を切断した8頭中 7 頭で左腰内臟神経の刺激による前立腺両葉の収縮, 前立腺液の分泌を認めた。

【考察】腰内蔵神経の刺激による前立腺収縮・前立腺液の分泌は片側の下腹神経を切断した後も 両側性に保たれ，交叉性支配経路が存在するものと考えられた。 